\title{
ANALISIS KEBUTUHAN PENGEMBANGAN BUKU AJAR BIOLOGI UMUM MATERI BIOTEKNOLOGI BERBASIS PENELITIAN UNTUK MAHASISWA S1 PENDIDIKAN BIOLOGI INSTTITUT TEKNOLOGI DAN SAINS NAHDLATUL ULAMA PASURUAN
}

\author{
Rizka Elan Fadilah \\ Institut Teknologi dan Sains Nahdlatul Ulama Pasuruan \\ e-mail: rizkaelan@gmail.com
}

\begin{abstract}
Abstrak: Tujuan dari penelitian ini adalah menganalisis kebutuhan pengembangan buku ajar Biologi Umum materi Bioteknologi untuk mahasiswa S1 Program Studi Pendidikan Biologi Institut Teknologi dan Sains Nahdlatul Ulama Pasuruan. Penelitian ini menggunakan teknik observasi, angket, dan wawancara. Berdasarkan analisis kebutuhan diketahui bahwa (1) capaian pembelajaran: mahasiswa mampu mendeskripsikan peranan bioteknologi dan mengimplementasikannya dalam kehidupan sehari-hari (2) materi yang disajikan dalam proses pembelajaran kurang aplikatif (3) mahasiswa kurang menggunakan sumber belajar yang baik (4) pemahaman mahasiswa terkait materi Bioteknologi masih tergolong rendah (5) mahasiswa sulit mengakses buku-buku perkuliahan. Hasil penelitian ini digunakan sebagai dasar pengembangan buku ajar Biologi Umum materi Bioteknologi berbasis penelitian untuk mahasiswa S1 Pendidikan Biologi Institut Teknologi dan Sains Nahdlatul Ulama Pasuruan.
\end{abstract}

Kata kunci: analisis kebutuhan, buku ajar berbasis penelitian, biologi umum, bioteknologi

\begin{abstract}
This study aims to analyze the need for the development of Biology textbooks on Biotechnology material for undergraduate students of the Biology Education Study Program at the Institute of Technology and Science in Nahdlatul Ulama Pasuruan. This research uses observation, questionnaires, and interviews. The results of the study known that (1) learning outcomes is that students are able to describe the role of biotechnology and implement it in daily life (2) the material presented in the learning process is still theoretically and less applicable (3) students lack of good learning resources (4 ) understanding of students in Biotechnology material is still relatively low (5) students find it difficult to access lecture books. The results of this study were used as the basis for the development of the Biology, especially Biotechnology, textbook on research-based for undergraduate students of Biology Education Study Program at the Institute of Technology and Science in Nahdlatul Ulama Pasuruan.
\end{abstract}

Keywords: needs analysis, research-based textbooks, biology, biotechnology 


\section{PENDAHULUAN}

Saat ini kemajuan teknologi adalah sesuatu yang tidak dapat dihindari karena akan selalu sejalan dengan kemajuan ilmu pengetahuan (Ngafifi, 2014). Perkembangan ilmu pengetahuan dan teknologi (IPTEK) tersebut juga telah memberikan pengaruh yang cukup besar dalam dunia pendidikan (Budiman, 2017). Pemanfaatan perkembangan IPTEK dalam pembelajaran juga telah dirumuskan dalam Kerangka Kualifikasi Nasional Indonesia (KKNI). Kualifikasi yang dirumuskan untuk mahasiswa $\mathrm{S} 1$ dalam KKNI berada pada level 6 (perpres, 2012) yaitu mampu mengaplikasikan bidang keahliannya dan memanfaatkan IPTEKS pada bidangnya dalam penyelesaian masalah serta mampu beradaptasi terhadap situasi yang dihadapi (Perpres, 2012).

Materi perkuliahan yang erat dengan perkembangan IPTEK terkini adalah bioteknologi. Bioteknologi merupakan salah satu materi dalam matakuliah Biologi Umum yang wajib ditempuh oleh mahasiswa pendidikan biologi di ITSNU Pasuruan. Bioteknologi merupakan teknologi yang berbasis biologi. Bioteknologi memanfaatkan sel dan berbagai proses biomolekular untuk mengembangkan produk dan teknologi dalam meningkatkan kualitas hidup dan kesehatan manusia (Mahboudi, 2012).

Kontekstualisasi pembelajaran penting dilakukan oleh mahasiswa karena merupakan salah satu tujuan pembelajaran yang terumus dalam KKNI. Salah satu upaya untuk mengkontekstualkan pembelajaran yaitu dengan mengimplementasikan hasil penelitian dalam pembelajaran (Amin,
2010). Implementasi hasil penelitian dalam pembelajaran tersebut dapat melalui pengembangan buku ajar berbasis penelitian (Fadilah, et al., 2016). Primiani (2014) menyatakan bahwa pengembangan buku ajar berbasis penelitian dapat memperluas dan memperdalam materi yang lebih aplikatif.

Penelitian ini bertujuan untuk menganalisis kebutuhan mahasiswa Program Studi Pendidikan Biologi jenjang S1 Institut Teknologi dan Sains Nahdlatul Ulama Pasuruan terhadap buku ajar materi Bioteknologi pada matakuliah Biologi Umum berdasar pada model pengembangan Dick and Carey (2009).

\section{TINJAUAN PUSTAKA}

Buku adalah bahan tertulis dalam bentuk lembaran-lembaran kertas yang dijilid dan diberi kulit (cover), yang menyajikan ilmu pengetahuan yang disusun secara sistematis oleh pengarangnya (Prastowo, 2012). Buku Ajar adalah buku yang digunakan oleh dosen sebagai sumber acuan dalam pelaksanaan proses pembelajaran bagi mahasiswanya. Buku ajar merupakan sarana pembelajaran yang signifikan untuk hampir semua mata kuliah dalam kurikulum (Program Pascasarjana Universitas Brawijaya, 2012)

Pengembangan buku ajar berbasis penelitian dapat mengupayakan pembelajaran yang lebih bersifat kontekstual. Parmin dan Peniati (2012) menyatakan bahwa hasil-hasil penelitian yang dimanfaatkan sebagai sumber belajar dan disusun dalam buku ajar dapat memberikan pengalaman nyata sehingga pembelajaran lebih bersifat kontekstual. 
Keunggulan dari buku ajar berbasis penelitian adalah dapat meningkatkan kebermaknaan mata kuliah supaya lebih kontekstual dengan penerapan hasil-hasil penelitian dan dapat mendorong mahasiswa untuk berpikir kreatif dari pemahaman akan inovasi dalam penelitian (Widayati et al, 2010).

Bioteknologi merupakan penerapan biosains dan teknologi yang melibatkan penerapan organisme hidup atau komponen subsellulernya pada industri jasa dan manufaktur serta pengelolaan lingkungan.

Bioteknologi dikelompokkan menjadi bioteknologi tradisional dan modern. Bioteknologi tradisional memanfaatkan mikrobia untuk memodifikasi bahan dan lingkungan untuk memperoleh produk optimal. Sedangkan bioteknologi modern memanfaatkan keterampilan manusia untuk memanipulasi makhluk hidup sebagai upaya untuk untuk menghasilkan produk sesuai dengan yang diinginkan manusia (Sutarno, 2016).

\section{METODE PENELITIAN}

Penelitian ini merupakan penelitian deskriptif kualitatif yang berfokus pada analisis kebutuhan pembelajaran Biologi Umum materi Bioteknologi. Subyek penelitian 14 mahasiswa program studi Pendidikan Biologi angkatan 2018 dan dosen pengampu matakuliah Biologi Umum. Tahap-tahap penelitian berdasar pada enam tahapan awal model pengembangan Dick and Carey (2009). Teknik pengumpulan data menggunakan angket, observasi, dan wawancara. Analisis data hasil wawancara dan observasi dilakukan secara deskriptif, sedangkan data hasil angket dilakukan secara deskriptif kuantitatif.

\section{HASIL DAN PEMBAHASAN}

Hasil dari tiap tahap penelitian berdasarkan model pengembangan Dick \& Carey (2009), sebagai berikut.

\section{a. Mengidentifikasi capaian pembelajaran (identify instructional goal)}

Pada tahap ini dilakukan identifikasi capaian pembelajaran yang harus dipenuhi setelah mahasiswa mengikuti pembelajaran matakuliah Biologi Umum materi Bioteknologi. Capaian pembelajaran diidentifikasi berdasarkan Rencana Pembelajaran Semester (RPS) matakuliah Biologi Umum materi Bioteknologi. Berdasarkan hasil identifikasi RPS diketahui bahwa capaian pembelajaran matakuliah Biologi Umum materi Bioteknologi adalah mahasiswa mampu mendeskripsikan peranan bioteknologi dan mengimplementasikannya dalam kehidupan sehari-hari.

\section{b. Melakukan analisis pembelajaran (conduct instructional analysis)}

Tahap ini dilakukan untuk menganalisis pengetahuan, sikap, dan keterampilan yang dibutuhkan mahasiswa untuk meraih capaian pembelajaran yang telah dirumuskan. Adapun pengetahuan, sikap, dan keterampilan yang dibutuhkan dapat dilihat pada Tabel 1 . 
Tabel 1. Pengetahuan, keterampilan, dan sikap yang dibutuhkan mahasiswa

\begin{tabular}{|c|c|}
\hline $\begin{array}{c}\text { Capaian } \\
\text { pembelajaran }\end{array}$ & $\begin{array}{c}\text { Pengetahuan/ } \\
\text { keterampilan / } \\
\text { sikap }\end{array}$ \\
\hline $\begin{array}{l}\text { mahasiswa } \\
\text { mampu } \\
\text { mendeskripsikan } \\
\text { peranan } \\
\text { bioteknologi dan } \\
\text { mengimplementas } \\
\text { ikannya dalam } \\
\text { kehidupan sehari- } \\
\text { hari. }\end{array}$ & $\begin{array}{l}\text { Mampu } \\
\text { menyebutkan } \\
\text { macam-macam } \\
\text { peranan } \\
\text { bioteknologi } \\
\text { konvensional } \\
\text { dan modern } \\
\text { Mampu } \\
\text { menjelaskan } \\
\text { pemanfaatan } \\
\text { enzim dalam } \\
\text { bioteknologi } \\
\text { Terampil } \\
\text { menerapkan } \\
\text { prinsip } \\
\text { bioteknologi } \\
\text { untuk } \\
\text { memecahkan } \\
\text { masalah }\end{array}$ \\
\hline
\end{tabular}

\section{c. Menganalisis mahasiswa dan konteks (analyze learner and contexts)}

Tahap analisis mahasiswa dan konteks ini dilakukan untuk mengetahui pengetahuan awal dan karakteristik mahasiswa yang dilakukan melalui observasi kelas, angket pendapat mahasiswa, dan wawancara terhadap dosen pengampu matakuliah Biologi Umum materi Bioteknologi. Berdasarkan hasil observasi pembelajaran diketahui bahwa materi yang disajikan mahasiswa masih bersifat teoritis. Mahasiswa tidak membahas tentang contoh-contoh kontekstual perkembangan bioteknologi modern terkini yang dapat dilakukan oleh mahasiswa sendiri.

Hasil wawancara terhadap dosen pengampu matakuliah Biologi Umum materi Bioteknologi menjelaskan bahwa terdapat beberapa kendala yang dialami selama pembelajaran, yaitu: mahasiswa kurang menggunakan sumber belajar yang baik. Mahasiswa cenderung menggunakan internet untuk mengakses materi-materi kuliah, namun sumbersumber yang digunakan cenderung sembarangan. Selain itu mahasiswa sulit untuk mengakses buku-buku perkuliahan karena belum adanya fasilitas perpustakaan kampus. Pemahaman mahasiswa terhadap materi bioteknologi masih tergolong rendah. Pembelajaran Biologi Umum secara umum belum mampu memenuhi tuntutan kurikulum KKNI yang mengharuskan mahasiswa untuk dapat mengaplikasikan konsepkonsep dalam menyelesaikan berbagai permasalahan.

Hasil wawancara tersebut juga bersinergi dengan hasil angket pendapat mahasiswa. Sebesar 57\% mahasiswa menyatakan bahwa kurang memahami konsep bioteknologi. Sebesar $43 \%$ siswa tidak menggunakan buku sebagai sumber belajar materi bioteknologi. Para mahasiswa tersebut cenderung menggunakan internet sebagai sumber belajar. Sedangkan 57\% mahasiswa yang mengaku menggunakan buku sebagai sumber belajar, ternyata buku yang digunakan adalah buku-buku tingkat SMA.

\section{d. Menyusun tujuan pembelajaran (write performance objectives)}

Tahap ini bertujuan untuk merumuskan tujuan spesifik pembelajaran berdasar pada hasil analisis pembelajaran di tahapan pengembangan sebelumnya. Tujuan pembelajaran yang telah dirumuskan, disajikan dalam Tabel 2. 
Rizka Elan Fadilah - Analisis Kebutuhan Pengembangan Buku Ajar Biologi Umum Materi Bioteknologi Berbasis Penelitian Untuk Mahasiswa S1 Pendidikan Biologi Insttitut Teknologi Dan Sains Nahdlatul Ulama Pasuruan

Tabel 2. Tujuan Pembelajaran

\begin{tabular}{|c|c|c|}
\hline $\begin{array}{c}\text { Capaian } \\
\text { pembelajaran }\end{array}$ & $\begin{array}{l}\text { Pengetahuan/ } \\
\text { keterampilan/ } \\
\text { sikap }\end{array}$ & $\begin{array}{c}\text { Tujuan } \\
\text { Pembelajaran }\end{array}$ \\
\hline $\begin{array}{l}\text { Mahasiswa } \\
\text { mampu } \\
\text { mendeskripsikan } \\
\text { peranan } \\
\text { bioteknologi dan } \\
\text { kemajuannya } \\
\text { bagi } \\
\text { kesejahteraan } \\
\text { manusia }\end{array}$ & $\begin{array}{l}\text { - Mendeskrips } \\
\text { ikan peranan } \\
\text { bioteknologi } \\
\text { konvensional } \\
\text { dan modern } \\
\text { - Terampil } \\
\text { menerapkan } \\
\text { bioteknologi } \\
\text { untuk } \\
\text { memecahkan } \\
\text { masalah } \\
\text { - Menjelaskan } \\
\text { dampak } \\
\text { bioteknologi } \\
\text { terhadap } \\
\text { kehidupan }\end{array}$ & $\begin{array}{l}\text { - Mahasiswa } \\
\text { mampu } \\
\text { menjelaskan } \\
\text { perbedaan } \\
\text { bioteknologi } \\
\text { konvensional } \\
\text { dan modern } \\
\text { - Mahasiswa } \\
\text { mampu } \\
\text { menyebutkan } \\
\text { contoh-contoh } \\
\text { bioteknologi } \\
\text { konvensional } \\
\text { dan modern } \\
\text { - Mahasiswa } \\
\text { mampu } \\
\text { menjelaskan } \\
\text { konsep } \\
\text { bioinformatika } \\
\text { Mahasiswa } \\
\text { terampil } \\
\text { menerapkan } \\
\text { bioteknologi } \\
\text { modern di } \\
\text { bidang farmasi } \\
\text { melalui } \\
\text { bioinformatika } \\
\text { untuk } \\
\text { memecahkan } \\
\text { masalah } \\
\text { kesehatan } \\
\text { Mahasiswa } \\
\text { mampu } \\
\text { menjelaskan } \\
\text { dampak } \\
\text { bioteknologi } \\
\text { modern bagi } \\
\text { kemajuan dan } \\
\text { kesejahteraan } \\
\text { manusia } \\
\text { aiasiana }\end{array}$ \\
\hline
\end{tabular}

\section{e. Mengembangkan penilaian (develop assessment instrument)}

Tahap pengembangan instrumen ini bertujuan untuk menentukan instrumen yang akan digunakan untuk mengetahui ketercapaian tujuan pembelajaran. Adapun instrumen yang akan digunakan disajikan dalam Tabel 3.

\section{Tabel 3. Jenis Instrumen Penilaian}

\begin{tabular}{|l|l|}
\hline Tujuan Pembelajaran & \multicolumn{1}{|c|}{ Jenis instrumen } \\
\hline - Mahasiswa mampu & Tes tulis pilihan ganda \\
menjelaskan & \\
perbedaan & Tes tulis pilihan ganda \\
bioteknologi & \\
konvensional dan & Tes tulis pilihan ganda \\
modern & Study kasus \\
- Mahasiswa mampu & \\
menyebutkan contoh- & Tes tulis esay \\
contoh bioteknologi & \\
konvensional dan & \\
modern & \\
- Mahasiswa mampu & \\
menjelaskan konsep & \\
bioinformatika & \\
- Mahasiswa terampil & \\
menerapkan & \\
bioteknologi modern \\
di bidang farmasi \\
melalui \\
bioinformatika untuk \\
memecahkan \\
masalah kesehatan \\
- Mahasiswa mampu \\
menjelaskan dampak \\
bioteknologi modern \\
bagi kemajuan dan \\
kesejahteraan \\
manusia
\end{tabular}

f. Mengembangkan strategi pembelajaran (develop instructional strategy)

Berdasarkan pada lima tahapan pengembangan yang telah dilakukan maka dapat dikembangkan buku ajar biologi umum materi bioteknologi berbasis penelitian dengan pendekatan bioinformatika untuk mahasiswa S1 Pendidikan Biologi Institut Teknologi dan Sains Nahdlatul Ulama Pasuruan. Buku ajar yang akan dikembangkan menggunakan pendekatan bioinformatika karena bioinformatika merupakan konseptualisasi biologi dalam bentuk makromolekul dan mengaplikasikan teknik informatika dalam memahami dan mengatur informasi yang terdapat dalam molekul tersebut, dalam skala yang lebih luas (Luscombe, et al., 2001). 
Bioinformatika tepat digunakan untuk mengkontekstualkan materi bioteknologi modern sehingga mahasiswa dapat mengimplementasikan bioteknologi modern dalam menyelesaikan suatu permasalahan.

Buku ajar berbasis penelitian dirasa dapat meningkatkan kemampuan mahasiswa untuk membantu memahami materi yang bersifat abstrak ke dalam bentuk yang lebih konkret atau nyata (Yahya, 2010).

\section{SIMPULAN DAN SARAN}

Berdasarkan hasil analisis kebutuhan dapat disimpulkan bahwa dibutuhkan pengembangan buku ajar Biologi Umum materi bioteknologi berbasis penelitian yang dapat menjadi sumber belajar yang baik bagi mahasiswa untuk memahami materi secara mendalam sesuai dengan capaian pembelajaran dan menggunakan pendekatan bioinformatika untuk mengaplikasikan materi bioteknologi sesuai dengan perkembangan IPTEK.

Buku ajar yang dikembangkan diharapkan membahas tentang materi bioteknologi dengan bahasa yang mudah dipahami serta langkah-langkah yang rinci dalam memanfaatkan bioinformatika untuk menyelesaikan suatu masalah.

\section{DAFTAR PUSTAKA}

Amin, M. (2010). Implementasi HasilHasil Penelitian Bidang Biologi Dalam Pemebelajaran. Proseding Seminar Biologi. Vol.1 No.7. (Online), (http://jurnal.fkip.uns.ac.id/inde x.php/prosbio/article/view/1202 , diakses 9 Maret 2019)
Budiman, Haris. 2017. Peran Teknologi Informasi Dan Komunikasi Dalam Pendidikan. AlTadzkiyyah: Jurnal Pendidikan Islam, Volume 8. P. ISSN: 20869118 E-ISSN: 2528-2476 (online)

(https://media.neliti.com/media/ publications/177430-ID-peranteknologi-informasi-dankomunikasi.pdf, diakses 7 Maret 2019)

Dick, W., Carey, L., and Carey, J.O. (2009). The Systematic Design of Instruction, Seventh Edition. USA: Pearson.

Fadilah, Rizka Elan, Amin, Mohamad., dan Lestari, Umi. 2016. Pengembangan Buku Ajar Evolusi Berbasis Penelitian untuk Mahasiswa S1 Pendidikan Biologi Universitas Jember. Jurnal Pendidikan: Teori, Penelitian, dan Pengembangan. Vol (1) (6). EISSN: 2502-471X. (online), (http://journal.um.ac.id/index.p hp/jptpp/articlel download/6425/2725, diakses 7 Maret 2019)

Luscombe, N.M., Greenbaum, D., Gerstain, M. What is bioinformatics? A proposed definition and overview of the field. Methods Inf Med 2001; 40(04): 346-358

DOI: $10.1055 / \mathrm{s}-0038-1634431$

(Online), (https://www.thiemeconnect.com/products/ ejournals/html/10.1055/s-00381634431, diakses 13 Maret 2019)

Mahboudi, F., Hamedifar, H., Aghajani, H. 2012. Medical

Biotechnology Trends and Achievements in Iran. Avicenna Journal of Medical Biotechnology, 4 (4): 200-205. 
Ngafifi, Muhamad. 2014. Kemajuan

Teknologi Dan Pola Hidup

Manusia Dalam Perspektif

Sosial Budaya. Jurnal

Pembangunan Pendidikan:

Fondasi dan Aplikasi Volume 2,

Nomor 1, 2014 (online)

(https://journal.uny.ac.id/index.

php/

jppfa/article/download/.../2171, diakses 2 Maret 2019)

Parmin dan Peniati, E. (2012).

Pengembangan Modul Mata

Kuliah Strategi Belajar

Mengajar IPA Berbasis Hasil

Penelitian Pembelajaran. Jurnal

Pendidikan IPA Indonesia 1 (1).

(Online)

(http://journal.unnes.ac.id/index

.php/jpii, diakses 13 Maret 2019).

Peraturan Presiden Republik Indonesia

Nomor 8 Tahun 2012 tentang

Kerangka Kualifikasi Nasional

Indonesia. (Online),

(http://sipma.ui.ac.id/files/doku

men/U_KKNI/Perpres0082012

Lampiran.pdf), diakses 21

Maret 2019.

Prastowo, Andi. 2012. Panduan Kreatif

Membuat Bahan Ajar Inovatif:

Menciptakan Metode

Pembelajaran yang Menarik dan

Menyenangkan. Diva Press:

Jogjakarta.

Primiani, C.A. 2014. Pengembangan

Buku Ajar Berbasis Penelitian
Bahan Alam Lokal sebagai

Estrogenik pada Matakuliah

Fisiologi Hewan. Prosiding

Mathematics and Sciences

Forum 2014. ISBN 978-602-

0960-00-5. (Online),

(http://prosiding.upgris.ac.id/ind

ex.php/masif2014/masif2014/pa

per/view/459/408, diakses 10

Maret 2019)

Program Pascasarjana Universitas

Brawijaya. 2012. Pedoman

Umum Penulisan Bahan Ajar

PDKLP. Program Pascasarjana

Universitas Brawijaya: Malang

Widayati, D.T., Luknanto, D.,

Rahayuningsih, E., Sutapa, G.,

Harsono, Sancayaningsih, R.P., dan Sajarwa. 2010. Pedoman

Umum Pembelajaran Berbasis

Riset (PUPBR). (online)

(ppp.ugm.ac.id/p3/wp-content) uploads/pupbrindonesia.pdf, diakses 10 Maret 2019)

Yahya, I. 2010. Manajemen Empat

Langkah dalam Pengembangan

Bahan Ajar Berbasis Riset:

Sebuah Pengalaman dari

Perkuliahan Akustik di Jurusan

Fisika FMIPA UNS. (Online),

(http://iwany.staff.uns.ac.id/201 0/10/19/files/2010/10/researchenhanced-

teaching_okt2010.pdf, diakses

13 Maret 2019) 